DOI: 10.20472/IAC.2017.032.003

\author{
ANA AKHVLEDIANI \\ Ivane Javakhishvili Tbilisi state university , Georgia
}

\title{
GEORGIAN PUBLIC DEBT TENDENCY AND ITS IMPACT ON THE ECONOMIC GROWTH
}

\begin{abstract}
:
This paper analyses the tendency of Georgian Public debt and its impact on the economic growth. Public debt plays important role in the process of developing state's macroeconomic system. It can be explained by the fact that debt arising and its services greatly affect the country's financial status, the size of the savings, the amount of money, the investment environment, the consumption structure and the international relationship with the rest of the country. It is very difficult to find a country in the whole world which did not face Public debt problem at least once. The issue of Public debt problem can be also explained by the fact that most countries have a tendency to increase debt. The burden of the debt affects on the economic and social conditions of the country and consequently, it is crucial for the government to find ways to solve it. Stabilization of internal and external debt is one of the most essential factors for long-term economic development of the country. Nowadays budget deficit is not surprising, it is well-known method to use debt obligations to fund deficits.

Current financial crisis in the modern world have changed the attitude of the countries to be more cautious when it comes to the Public debt. Public debt is mostly used to finance social and economic needs. Country's solvency and its international reputation is related to the Public debt, so it is very important for any country to determine the exact amount of Public debt and develop an optimal system of management.

Based on the above mentioned, this paper studies Georgian public debt effects on the economic growth, the debt management methods and ways of spending. As a result of this study, Georgian Public debt appears not to be big burden for the country, but it has the tendency of growing. At the same time, various problems have been identified in the debt management process.
\end{abstract}

\section{Keywords:}

debt, impact, management.

JEL Classification: H63, H69 